\title{
Type 2 inflammation in asthma
}

\author{
Insu YILMAZ(ID) \\ Bahar ARSLAN $(I D)$
}

Cite this article as: Yılmaz i, Arslan B. Type 2 inflammation in asthma. Tuberk Toraks 2021;69(1):114-115.

\section{Yazışma Adresi (Address for Correspondence)}

\section{Dr. İnsu YILMAZ}

Erciyes Üniversitesi Tıp Fakültesi, Gögüs Hastalıkları Anabilim Dalı, İmmünoloji ve Allerji Bilim Dalı, KAYSERI - TÜRKIYE

e-mail: insu2004@yahoo.com

CCopyright 2021 by Tuberculosis and Thorax.

Available on-line at www.tuberktoraks.org.com
Department of Chest Diseases, Division of Immunology and Allergy, Erciyes University Faculty of Medicine, Kayseri, Turkey

Erciyes Üniversitesi Tıp Fakültesi, Göğüs Hastalıkları Anabilim Dalı, Immünoloji ve Allerji Bilim Dalı, Kayseri, Türkiye

To the Editor,

Asthma has been classified as Type 2 (T2) and non-T2 asthma according to the underlying inflammation (1). Terms such as "T2 asthma", "T2 asthma endotype", "T2 asthma phenotype", and "T2 inflammation" are frequently encountered in the literature. All these terms refer to similar situations, even if their terminologies differ. T2 asthma phenotype defines the classification of asthma based on observable and clinical features of T2 inflammation. T2 asthma and T2 asthma endotype refer to the underlying inflammation type in asthma. However, T2 inflammation is a more general notion. It is one of the underlying inflammatory pathways in chronic rhinosinusitis/nasal polyposis, rhinitis, asthma, and atopic dermatitis, chronic rhinosinusitis/nasal polyposis, rhinitis, asthma, and atopic dermatitis. It encompasses all cytokines, effector cells, and mediators that make up the T2 inflammation underlies these diseases.

T2 inflammation in asthma can be defined as:

- An adaptive immune response (Th2 cells) and/or an innate immune response [innate lymphocyte cells (ILC) 2] activation, and cytokines such as IL-4, IL-5, IL-9, IL-13 released from the cells as downstream cytokines that regulate and generate inflammation.

- Specific IgE (IgE secretion via B lymphocytes in response to aeroallergens) and prostaglandin D2-prostaglandin D2 receptor pathway, effector cells such as eosinophils and mast cells, and mediators released from them can be involved in the inflammation. 
- Cytokines such as IL-33, IL-25, Thymic stromal lymphopoietin are danger signals also known as "alarmins" released after epithelial damage with allergens, superantigens, toxic agents, irritants, and viruses. These alarmins trigger the ILC2 and Th2 response. ILC2 is primarily regulated by the alarmins.

- These cells, mediators, cytokines, and antibodies can form different endotypes (subendotype: dominant T2 inflammatory pathway of type 2 endotype).

If the patient does not have atopy but has eosinophilia, this may reflect that T2 inflammation's ILC2 pathway (IL5, IL13 dominant pathway) is more active. If there is pure atopy (skin-prick test positivity, respiratory symptoms triggered by aeroallergen exposure, family history of atopy, early age, comorbidities such as allergic rhinitis/atopic dermatitis). It suggests that T2 inflammation's Th2 pathway (IgE dominant pathway) is active (2).

Patients with a lack of evidence of type 2 inflammation are referred to as non-T2 or T2-low asthma. Asthma patients with a non-T2 phenotype usually develop airway disease at an older age, do not have typical comor- bid diseases of T2 asthma (e.g., food allergy, atopic dermatitis, allergic rhinitis, nasal polyposis), and have limited or no specific sensitivity to IgE (3). Patients with non-T2 asthma have been shown to have a predominance of neutrophils in the sputum or minimal pathological signs of active inflammation (paucigranulocytic) (4). A reliable biomarker for this asthma subtype has not been developed. Therefore, the diagnosis of a T2-low asthma phenotype is usually made due to not detecting the elevation of $\mathrm{T} 2$ biomarkers.

\section{REFERENCES}

1. Wenzel SE. Emergence of biomolecular pathways to define novel asthma phenotypes. Type-2 immunity and beyond. Am J Respir Cell Mol Biol 2016; 55: 1-4.

2. McGregor MC, Krings JG, Nair P, Castro M. Role of biologics in asthma. Am J Respir Crit Care Med 2019; 199: 43345.

3. Samitas K, Zervas E, Gaga M. T2-low asthma: current approach to diagnosis and therapy. Curr Opin Pulm Med 2017; 23: 48-55.

4. Busse WW. Biological treatments for severe asthma: a major advance in asthma care. Allergol Int 2019; 68: 15866. 